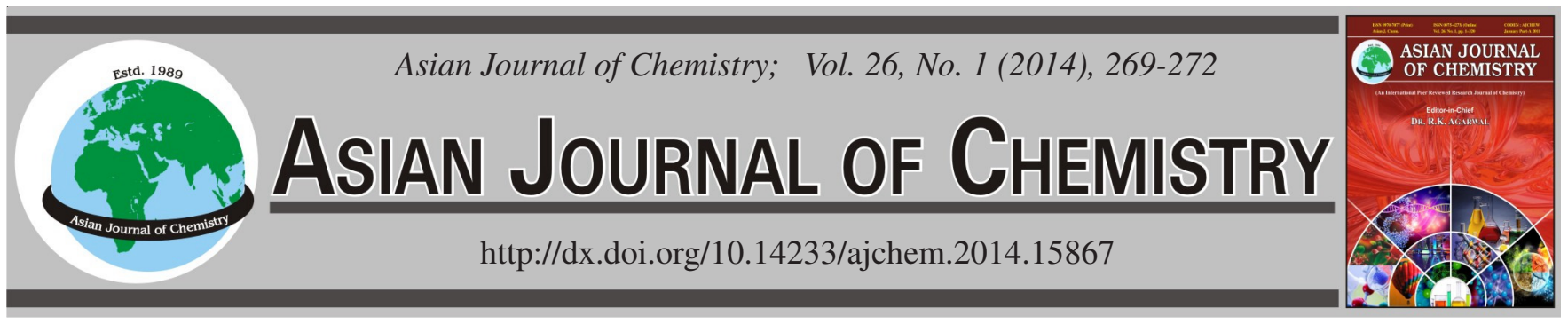

\title{
Synthesis and Crystal Structure of Trinuclear Ni(II) Complex with 5-Methoxy-4'-bromo-2,2'-[ethylenedioxybis(nitrilomethylidyne)]diphenol
}

\author{
Yu-Hua Yang, Xin-Ying Zhang, Xiu-Yan Dong ${ }^{*}$, Gang Li and Meng-Meng ZhaO
}

School of Chemical and Biological Engineering, Lanzhou Jiaotong University, Lanzhou 730070, P.R. China

*Corresponding author: E-mail: dxy568@163.com

A Ni(II) complex with 5-methoxy-4'-bromo-2,2'-[ethylenedioxybis(nitrilomethylidyne)]diphenol $\left(\mathrm{H}_{2} \mathrm{~L}\right)$ has been synthesized, with the formula $\left\{[\mathrm{NiL}(n \text {-butanol })(\mu-\mathrm{OAc})]_{2} \mathrm{Ni}\right\} \cdot n$-butanol. The crystal of the $\mathrm{Ni}(\mathrm{II})$ complex belongs to triclinic, space group $\mathrm{P}-1$ with cell dimensions $\mathrm{a}=10.897(1) \AA, \mathrm{b}=12.439(1) \AA, \mathrm{c}=12.518(1) \AA$ and $\mathrm{Z}=1$. In the Ni(II) complex, there are three Ni(II) atoms, two deprotonated $\mathrm{L}^{2-}$ moieties which provide $\mathrm{N}_{2} \mathrm{O}_{2}$ donors, two acetate anions, two coordinated and one non-coordinated $n$-butanol molecules, which result in the formation of a slightly distorted octahedral coordination geometry around each $\mathrm{Ni}(\mathrm{II})$ atom, respectively.

Keywords :Asymmetric Salamo-type ligand, Ni(II) complex, Synthesis, Crystal structure.

\section{INTRODUCTION}

Transition metal complexes of Salen-type ligands have attracted much interest in the last few decades due to their unique catalytic activity ${ }^{1,2}$, photonic devices ${ }^{3,4}$, biological activity $^{5,6}$ and magnetic properties ${ }^{7-9}$, such as epoxidation catalysts, in the presence of a terminal oxidant like iodosylbenzene $^{10-14}$, N-salicylideneanilines constitute an important family of photochromic compounds ${ }^{3,4}$. This photochromism has also been observed for the derivative Salen-type compound $^{15}$. Furthermore, Salen-Ni(II) complexes are used extensively in the design and construction of new magnetic materials and models for the $\mathrm{Ni}$ (II) centers of enzymes. Hence, structural characteristics of transition metal complexes with Salen-type ligands may be a valuable source of information. Transition metal complexes of Salen-type ligands with oxygen and nitrogen donors are of particular interest ${ }^{16,17}$ because of their ability to possess excellent properties ${ }^{18-20}$.

Therefore, we here describe the synthesis and crystal structure of a trinuclear $\mathrm{Ni}$ (II) complex containing the asymmetric ligand 5-methoxy-4'-bromo-2,2'-[ethylenedioxybis(nitrilomethylidyne)]diphenol $\left(\mathrm{H}_{2} \mathrm{~L}\right)$.

\section{EXPERIMENTAL}

2-Hydroxy-4-methoxybenzaldehyde $(\geq 99 \%)$ and 2-hydroxy-5-bromobenzaldehyde ( $\geq 99 \%$ ) were purchased from Alfa Aesar and used without further purification. 1,2Bis(aminooxy)ethane was synthesized according to an analogous method reported earlier ${ }^{21-25}$. The other reagents and solvents were analytical grade from Tianjin Chemical Reagent Factory. Elemental analysis for Ni was detected by an IRIS ER/S.WP-1 ICP atomic emission spectrometer. C, $\mathrm{H}$ and $\mathrm{N}$ analyses were obtained using a GmbH VarioEL V3.00 automatic elemental analysis instrument. X-ray single crystal structure determination was carried out on a Bruker Smart 1000 CCD diffractometer. Melting points were measured by the use of a microscopic melting point apparatus made in Beijing Taike Instrument Limited Company and the thermometer was uncorrected.

Synthesis of $\mathbf{H}_{2} \mathbf{L}$ : The main reaction steps involved in the synthesis of $\mathrm{H}_{2} \mathrm{~L}$ are given in Scheme-I. $\mathrm{H}_{2} \mathrm{~L}$ was synthesized according to an analogous method reported earlier ${ }^{24}$. Yield 73.8 \%. m.p. 385-387 K. Anal. Calcd. for $\mathrm{C}_{17} \mathrm{H}_{17} \mathrm{~N}_{2} \mathrm{O}_{5} \mathrm{Br}$ (\%): C, 49.89; H, 4.19; N, 6.85. Found: C, 49.75; H, 4.32; N, 6.99 .

Synthesis of $\mathrm{Ni}(\mathrm{II})$ complex: A solution of $\mathrm{Ni}(\mathrm{OAc})_{2} \cdot 4 \mathrm{H}_{2} \mathrm{O}$ (3.70 $\mathrm{mg}, 0.015 \mathrm{mmol})$ in $n$-butanol $(2 \mathrm{~mL})$ was added dropwise to a solution of $\mathrm{H}_{2} \mathrm{~L}(4.10 \mathrm{mg}, 0.010 \mathrm{mmol})$ in acetonitrile $(2 \mathrm{~mL})$ at room temperature. The color of the mixing solution turned green immediately and then stirring was continued for $0.5 \mathrm{~h}$ at room temperature. The mixture was filtered off and the filtrate was allowed to stand at room temperature for about 1 month, the solvent was partially evaporated and obtained green prismatical single crystals suitable for $\mathrm{X}$-ray crystallographic analysis. Anal. calcd. for $\mathrm{C}_{54} \mathrm{H}_{76} \mathrm{~N}_{4} \mathrm{O}_{18} \mathrm{Ni}_{3} \mathrm{Br}_{2}(\%)$ : C, 46.16; H, 5.45; N, 3.99; Ni, 12.53 . Found: C, 46.37; H, 5.59; N, 3.82; Ni, 12.38 . 

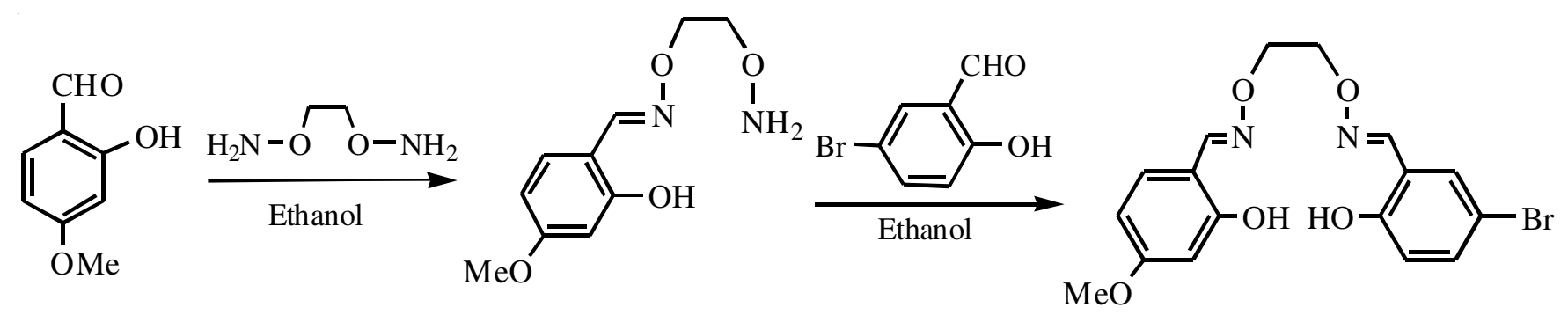

$\mathrm{H}_{2} \mathrm{~L}$

Scheme-I: Synthetic route to the asymmetrical Salamo-type ligand $\mathrm{H}_{2} \mathrm{~L}$

$\mathrm{X}$-ray structure determination: The crystal data and structure refinement for the $\mathrm{Ni}$ (II) complex are given in Table1. The single crystal of the Ni(II) complex with the approximate dimensions of $0.28 \mathrm{~mm} \times 0.20 \mathrm{~mm} \times 0.14 \mathrm{~mm}$ was placed on a Bruker Smart 1000 CCD area detector. The reflections were collected using a graphite monochromated MoKa radition $(\lambda=0.71073 \AA)$ at $298(2) \mathrm{K}$. The structure was solved by using the program SHELXL-97 and Fourier difference techniques and refined by the full-matrix least-squares method on $\mathrm{F}^{2}$. The non-hydrogen atoms were refined anisotropically. All hydrogen atoms were added theoretically. CCDC: 942408.

\begin{tabular}{|c|c|}
\hline \multicolumn{2}{|c|}{$\begin{array}{l}\text { TABLE-1 } \\
\text { CRYSTAL DATA AND STRUCTURE } \\
\text { REFINEMENT FOR Ni(II) COMPLEX }\end{array}$} \\
\hline Empirical formula & $\mathrm{C}_{54} \mathrm{H}_{76} \mathrm{Br}_{2} \mathrm{~N}_{4} \mathrm{Ni}_{3} \mathrm{O}_{18}$ \\
\hline Formula weight & 1405.14 \\
\hline Temperature (K) & $298(2)$ \\
\hline Wavelength $(\AA)$ & 0.71073 \\
\hline Crystal system & Triclinic \\
\hline Space group & P-1 \\
\hline Cell dimensions, $(\AA ̊ 丿$, deg $)$ & $\begin{array}{l}a=10.8973(11), \\
b=12.4386(13), \\
c=12.5175(14), \\
\alpha=77.601(1), \beta=88.596(2), \\
\gamma=67.837(1)\end{array}$ \\
\hline Volume $\left(\AA^{3}\right)$ & $1531.7(3)$ \\
\hline$Z$ & 1 \\
\hline Density (calculated) $\left(\mathrm{mg} / \mathrm{m}^{3}\right)$ & 1.523 \\
\hline Absorption coefficient $\left(\mathrm{mm}^{-1}\right)$ & 2.288 \\
\hline$F_{(000)}$ & 726 \\
\hline Index ranges & $\begin{array}{l}-12 \leq \mathrm{h} \leq 12,-14 \leq \mathrm{k} \leq 12,-14 \leq 1 \\
\leq 14\end{array}$ \\
\hline Reflections collected & $7571 / 5263[\mathrm{R}(\mathrm{int})=0.0719]$ \\
\hline Independent reflections & 1119 \\
\hline Data/restraints/parameters & $5263 / 0 / 408$ \\
\hline Goodness of fit indicator & 1.009 \\
\hline $\mathrm{R}[\mathrm{I}>2 \sigma(\mathrm{I})]$ & $\mathrm{R}_{1}=0.0307, \mathrm{wR}_{2}=0.1167$ \\
\hline Largest diff. peak and hole $\left(\mathrm{e} \AA^{-3}\right)$ & 1.099 and -0.910 \\
\hline
\end{tabular}

\section{RESULTS AND DISCUSSION}

Crystal structure of $\mathrm{Ni}$ (II) complex: X-ray crystal structure shows that there are three hexa-coordinated $\mathrm{Ni}(\mathrm{II})$ atoms with a linear array, two deprotonated $\mathrm{L}^{2-}$ moieties, two acetate anions, as well as two coordinated and one non-coordinated $n$-butanol molecules in the Ni(II) complex, which result in the formation of the slightly distorted octahedral coordination geometries around each $\mathrm{Ni}$ (II) atom, respectively. The molecular structure is shown in Fig. 1. Selected bond lengths and angles are given in Table-2.

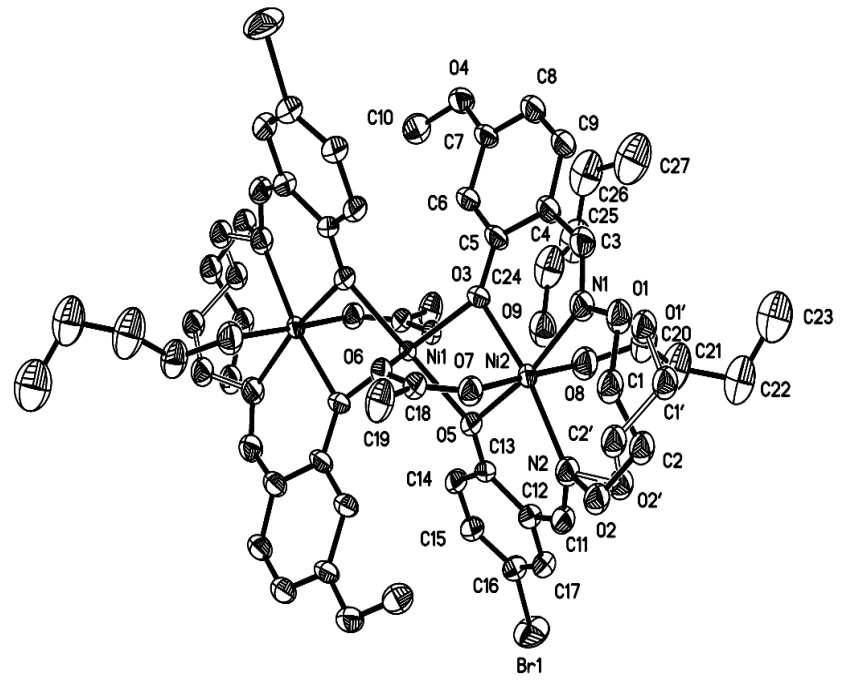

Fig. 1. Molecular structure of Ni(II) complex

In the crystal structure, the $\mathrm{Ni}(\mathrm{II})$ complex belongs to triclinic, space group P-1 with cell dimensions a $=10.897(1)$ $\AA, b=12.439$ (1) $\AA, c=12.518(1) \AA$ and $\mathrm{Z}=1$. The two terminal $\mathrm{Ni}(\mathrm{II})\left(\mathrm{Ni} 2\right.$ and $\mathrm{Ni2}{ }^{21}$ ) atoms are coordinated by two nitrogen $(\mathrm{N} 1, \mathrm{~N} 2)$ atoms and two oxygen $(\mathrm{O} 3$ and $\mathrm{O} 5)$ atoms in the $\mathrm{N}_{2} \mathrm{O}_{2}$ moieties of the $\mathrm{L}^{2-}$ moieties, one oxygen $(\mathrm{O} 7)$ atom from the bridging acetate anion and one oxygen (O8) atom from the coordinated $n$-butanol molecule in the axial positions. The dihedral angel between the two coordination planes, N1$\mathrm{Ni2}-\mathrm{O} 3$ and N2-Ni2-O5 is 3.22(3) ${ }^{\circ}$. Meanwhile, $\mathrm{Ni}(\mathrm{II})$ (Ni1) atom is located on a centre of inversion and has an $\mathrm{O}_{2} \mathrm{O}_{2}$ donor set from four $\mu$-phenoxo oxygen $\left(\mathrm{O} 3, \mathrm{O} 5, \mathrm{O} 3^{\# 1}\right.$ and $\left.\mathrm{O}^{\# 1}\right)$ atoms from two $\mathrm{L}^{2-}$ units and two $\mu$-acetato oxygen (O6 and $\mathrm{O}^{\# 1}$ ) atoms, which adopt a familiar $\mu-\mathrm{O}-\mathrm{C}-\mathrm{O}$ fashion and constitute another octahedral geometry. Furthermore, The interatomic distance of Ni2-Ni1 (3.087(4) $\AA$ ) is significantly longer than all that of the Ni-O and Ni-N bonds in the Ni(II) complex, which is also essentially similar to previously reported octanuclear analogue of $\left[\mathrm{Zn}_{8} \mathrm{~L}_{4}\left(\mathrm{H}_{2} \mathrm{O}\right)_{2} \mathrm{X}\right] \cdot 2 \mathrm{H}_{2} \mathrm{O} \cdot 1.5 \mathrm{CHCl}_{3}$. 0.5 hexane $\left(\mathrm{X}=\mathrm{H}_{2} \mathrm{O} \text { or EtOH }\right)^{26}$. In addition, the trinuclear structure is probably stabilized by the two $\mu$-acetato moieties, which neutralize the whole charge of the $\mathrm{Ni}(\mathrm{II})$ complex.

Intermolecular interactions of the $\mathrm{Ni}$ (II) complex: In the crystal structure of the $\mathrm{Ni}$ (II) complex, there are weak intramolecular C1-H1 A …07 hydrogen bonds (Fig. 2), as well as strong intermolecular $\mathrm{O} 8-\mathrm{H} 8 \cdots \mathrm{O} 9, \mathrm{O} 9-\mathrm{H} 9 \cdots \mathrm{O} 6$ and $\mathrm{C} 25-$ $\mathrm{H} 25 \mathrm{~A} \cdots \mathrm{O} 9$ hydrogen bonds that stabilize the structure of the $\mathrm{Ni}(\mathrm{II})$ complex. Hydrogen bond data are given in Table-3. 
TABLE-2

SELECTED BOND LENGTHS $(\AA ̊)$ AND ANGLES $\left({ }^{\circ}\right)$ FOR THE COMPLEX

\begin{tabular}{|c|c|c|c|c|c|}
\hline Bond & Lengths & Bond & Lengths & Bond & Lengths \\
\hline $\mathrm{Ni1}^{-O 3^{\# 1}}$ & $2.080(11)$ & $\mathrm{Ni1}^{-\mathrm{O6}^{\# 1}}$ & $2.124(13)$ & Ni2-O7 & $2.047(15)$ \\
\hline Ni1-O3 & $2.080(11)$ & Ni1-O6 & $2.124(13)$ & Ni2-N1 & $2.066(18)$ \\
\hline $\mathrm{Ni1}-\mathrm{O}^{\# 1}$ & $2.094(11)$ & $\mathrm{Ni2}-\mathrm{O} 5$ & $2.017(12)$ & Ni2-N2 & $2.098(17)$ \\
\hline $\mathrm{Ni1-O5}$ & $2.094(11)$ & $\mathrm{Ni2}-\mathrm{O} 3$ & $2.031(12)$ & $\mathrm{Ni2}-\mathrm{O} 8$ & $2.126(17)$ \\
\hline Bond & Angles & Bond & Angles & Bond & Angles \\
\hline $\mathrm{O}^{\# 1}-\mathrm{Ni} 1-\mathrm{O} 3$ & $180.0(1)$ & O5-Ni2-O3 & $81.1(5)$ & C3-N1-Ni2 & $124.8(16)$ \\
\hline $\mathrm{O} 3^{\# 1}-\mathrm{Ni} 1-\mathrm{O}^{\# 1}$ & $78.2(4)$ & $\mathrm{O} 5-\mathrm{Ni} 2-\mathrm{O} 7$ & $91.1(5)$ & O1'-N1-Ni2 & $118(3)$ \\
\hline O3-Ni1-O5 ${ }^{\# 1}$ & $101.8(4)$ & $\mathrm{O} 3-\mathrm{Ni} 2-\mathrm{O} 7$ & $91.4(5)$ & O1-N1-Ni2 & $127.1(15)$ \\
\hline $\mathrm{O}^{\# 1}-\mathrm{Ni1}-\mathrm{O} 5$ & $101.8(4)$ & $\mathrm{O} 5-\mathrm{Ni} 2-\mathrm{N} 1$ & $168.2(6)$ & $\mathrm{C} 11-\mathrm{N} 2-\mathrm{Ni} 2$ & $122.9(14)$ \\
\hline O3-Ni1-O5 & $78.2(4)$ & O3-Ni2-N1 & $87.5(6)$ & $\mathrm{O} 2-\mathrm{N} 2-\mathrm{Ni} 2$ & $128(2)$ \\
\hline $\mathrm{O}^{\# 1}-\mathrm{Ni} 1-\mathrm{O} 5$ & $180.0(7)$ & O7-Ni2-N1 & $92.4(7)$ & $\mathrm{O} 2$ '-N2-Ni2 & $125(5)$ \\
\hline $\mathrm{O} 3^{\# 1}-\mathrm{Ni} 1-\mathrm{O} 6^{\# 1}$ & $88.1(5)$ & O5-Ni2-N2 & $87.2(6)$ & $\mathrm{C} 5-\mathrm{O} 3-\mathrm{Ni2}$ & $127.5(12)$ \\
\hline O3-Ni1-O6 ${ }^{\# 1}$ & $91.9(5)$ & $\mathrm{O} 3-\mathrm{Ni} 2-\mathrm{N} 2$ & $168.3(6)$ & C5-O3-Ni1 & $133.0(12)$ \\
\hline $\mathrm{O}^{\# 1}-\mathrm{Ni} 1-\mathrm{O}^{\# 1}$ & $88.5(5)$ & O7-Ni2-N2 & $88.7(6)$ & Ni2-O3-Ni1 & $97.4(4)$ \\
\hline O5-Ni1-O6 ${ }^{\# 1}$ & $91.5(5)$ & N1-Ni2-N2 & $104.2(7)$ & $\mathrm{C} 13-\mathrm{O} 5-\mathrm{Ni} 2$ & $125.5(11)$ \\
\hline $\mathrm{O}^{\# 1}-\mathrm{Ni1}-\mathrm{O} 6$ & $91.9(5)$ & $\mathrm{O} 5-\mathrm{Ni} 2-\mathrm{O} 8$ & $89.7(6)$ & C13-O5-Ni1 & 133.1(11) \\
\hline O3-Ni1-O6 & $88.1(5)$ & O3-Ni2-O8 & $90.4(6)$ & Ni2-O5-Ni1 & $97.3(5)$ \\
\hline $\mathrm{O}^{\# 1}$-Ni1-O6 & $91.5(5)$ & O7-Ni2-O8 & $178.1(6)$ & C18-O6-Ni1 & $129.1(13)$ \\
\hline O5-Ni1-O6 & $88.5(5)$ & N1-Ni2-O8 & $87.2(7)$ & $\mathrm{C} 18-\mathrm{O} 7-\mathrm{Ni} 2$ & $130.2(14)$ \\
\hline $\mathrm{O6}^{\# 1}$-Ni1-O6 & $180.0(2)$ & $\mathrm{N} 2-\mathrm{Ni} 2-\mathrm{O} 8$ & $89.6(7)$ & $\mathrm{C} 20-\mathrm{O} 8-\mathrm{Ni} 2$ & $118.8(17)$ \\
\hline
\end{tabular}

TABLE-3

DATA FOR HYDROGEN-BONDING INTERACTIONS (Å)

\begin{tabular}{|c|c|c|c|c|c|}
\hline D-H $\cdots A$ & $\mathrm{~d}(\mathrm{D}-\mathrm{H})$ & $\mathrm{d}(\mathrm{H} \cdots \mathrm{A})$ & $d(D \cdots A)$ & $\angle \mathrm{D}-\mathrm{H} \cdots \mathrm{A}$ & Symmetry code \\
\hline 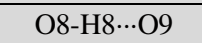 & 0.82 & 1.77 & $2.59(3)$ & 173 & $\mathrm{x}, \mathrm{y}, \mathrm{z}$ \\
\hline 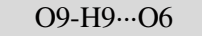 & 0.82 & 1.95 & $2.76(2)$ & 169 & $1-x, 1-y, 1-z$ \\
\hline $\mathrm{C} 25-\mathrm{H} 25 \mathrm{~A} \cdots \mathrm{O} 9$ & 0.97 & 2.30 & $2.89(6)$ & 118 & $1-x, 1-y,-z$ \\
\hline 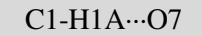 & 0.97 & 2.35 & $3.19(5)$ & 143 & $\mathrm{x}, \mathrm{y}, \mathrm{z}$ \\
\hline
\end{tabular}

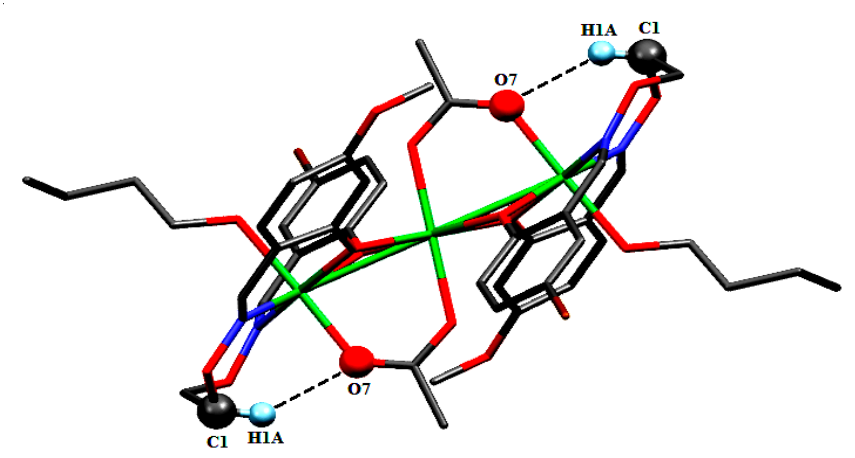

Each oxygen (O9) atom of the non-coordinated $n$-butanol molecule is hydrogen-bonded to the - $\mathrm{O} 8 \mathrm{H} 8$ group of the coordinated $n$-butanol molecule and the -C25H25A group of the another non-coordinated $n$-butanol molecule, respectively, while its -O9H9 group is hydrogen-bonded to the $\mu$-acetato oxygen (O6) atoms. Thus, each $\mathrm{Ni}(\mathrm{II})$ complex links two non-coordinated $n$-butanol molecules by intermolecular

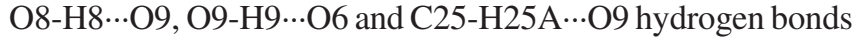
into an infinite $1 \mathrm{D}$ chain along the $c$-axis (Fig. 3).

Fig. 2. View of the intramolecular hydrogen-bonding interactions of the complex

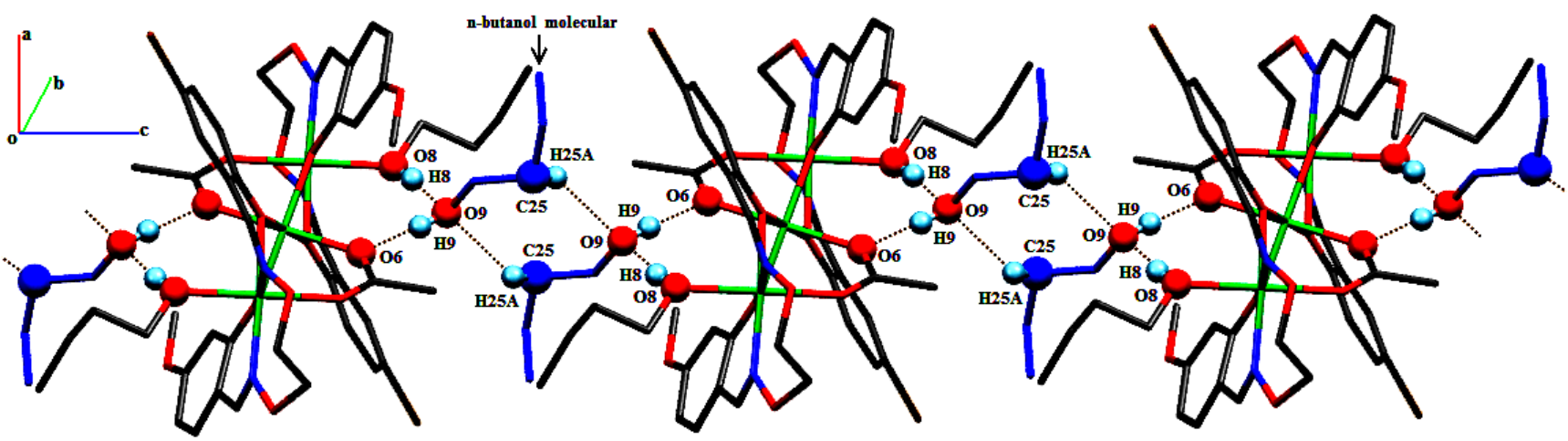

Fig. 3. View of the 1D chain motif of the Ni(II) complex units along the $c$ axis (hydrogen atoms, except those forming hydrogen bonds, are omitted for clarity) 


\section{REFERENCES}

1. S.S. Sun, C.L. Stern, S.T. Nguyen and J.T. Hupp, J. Am. Chem. Soc., 126, 6314 (2004).

2. T. Katsuki, Coord. Chem. Rev., 140, 189 (1995).

3. E. Hadjoudis, M. Vittorakis and I. Moustakali-Mavidis, Tetrahedron, 43, 1345 (1987).

4. E. Hadjoudis, Mol. Eng., 5, 301 (1995).

5. P.G. Lacroix, Eur. J. Inorg. Chem., 339 (2001).

6. E. Keskioglu, A.B. Gündüzalp, S. Cete, F. Hamurcu and B. Erk, Spectrochim. Acta A, 70, 634 (2008).

7. T.K. Ronson, H. Adams and M.D. Ward, Inorg. Chim. Acta, 358, 1943 (2005).

8. Y.H. Feng, C. Wang, J.X. Xu, L. Xu, D.Z. Liao, S.P. Yan and Z.H. Jiang, Inorg. Chem. Commun., 11, 549 (2008).

9. Y.H. Feng, C. Wang, G.F. Xu, Y. Ouyang, D.Z. Liao and S.P. Yan, Inorg. Chem. Commun., 11, 341 (2008).

10. J.F. Larrow, E.N. Jacobsen, Y. Gao, Y. Hong, X. Nie and C.M. Zepp, J. Org. Chem., 59, 1993 (1994).

11. W. Zhang and E.N. Jacobsen, J. Org. Chem., 56, 2296 (1991).

12. K. Srinivasn, P. Michaud and J.K. Kochi, J. Am. Chem. Soc., 108, 2309 (1986).

13. E.N. Jacobsen, W. Zhang and M.L. Guler, J. Am. Chem. Soc., 113, 6703 (1991)

14. D.R. Oki and D.J. Hodgsen, Inorg. Chim. Acta, 170, 65 (1990).

15. J. Zjao, B. Zhao, J. Liu, A. Ren and J. Feng, Chem. Lett., 385 (2000).

16. Z.L. You, H.L. Zhu and W.S. Liu, Z. Anorg. Allg. Chem., 630, 1617 (2004).
17. Z.L. You and H.L. Zhu, Z. Anorg. Allg. Chem., 630, 2754 (2004).

18. K. Ogawa and T. Fujiwara, Chem. Lett., 28, 657 (1999).

19. E. Ito, H. Oji, T. Araki, K. Oichi, H. Ishii, Y. Ouchi, T. Ohta, N. Kosugi, Y. Maruyama, T. Naito, T. Inabe and K. Seki, J. Am. Chem. Soc., 119, 6336 (1997).

20. E. Hadjoudis, T. Dziembowska and Z. Rozwadowski, J. Photochem. Photobiol. A: Chem., 128, 97 (1999).

21. M. Maneiro, M.R. Bermejo, M. Fondo, A.M. González, J. Sanmartin, J.C. Garcia-Monteagudo, R.G. Pritchard and A.M. Tyryshkin, Polyhedron, 20, 711 (2001).

22. H.B. Zhu, Z.Y. Dai, W. Huang, K. Cui, S.H. Gou and C.J. Zhu, Polyhedron, 23, 1131 (2004).

23. S. Akine, T. Matsumoto, S. Sairenji and T. Nabeshima, Supramol. Chem., 23, 106 (2011).

24. (a) W.K. Dong, X.N. He, H.B. Yan, Z.W. Lv, X. Chen, C.Y. Zhao and X.L. Tang, Polyhedron, 28, 1419 (2009); (b) W.K. Dong, S.J. Xing, Y.X. Sun, L. Zhao, L.Q. Chai and X.H. Gao, J. Coord. Chem., 65, 1212 (2012); (c) W.K. Dong, Y.X. Sun, Y.P. Zhang, L. Li, X.N. He and X.L. Tang, Inorg. Chim. Acta, 362, 117 (2009); (d) W.K. Dong, Y.X. Sun, C.Y. Zhao, X.Y. Dong and L. Xu, Polyhedron, 29, 2087 (2010); (e) W.K. Dong, L. Li, C.F. Li, L. Xu and J.G. Duan, Spectrochimica Acta Part A, 71, 650 (2008); (f) W.K. Dong, Y.X. Sun, G.H. Liu, L. Li, X.Y. Dong and X.H. Gao, Z. Anorg. Allg. Chem., 638, 1370 (2012); (g) W.K. Dong, J.G. Duan, Y.H. Guan, J.Y. Shi and C.Y. Zhao, Inorg. Chim. Acta, 362, 1129 (2009).

25. A.D. Khalaji, M. Amirnasr and S. Triki, Inorg. Chim. Acta, 362, 587 (2009).

26. S. Akine, W.K. Dong and T. Nabeshima, Inorg. Chem., 45, 4677 (2006). 